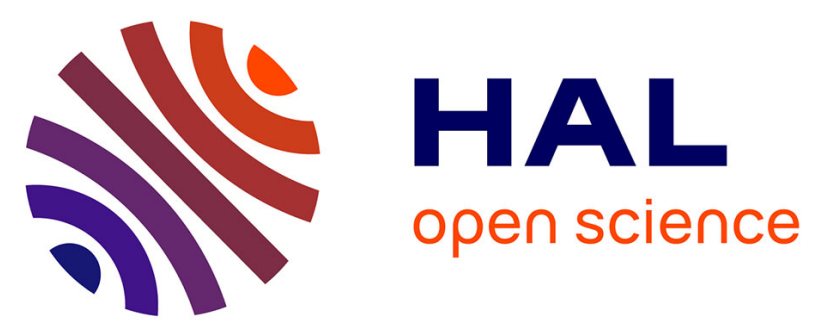

\title{
A MOLECULAR CASE-CONTROL STUDY ON THE MERKEL CELL POLYOMAVIRUS IN COLON CANCER
}

Cesare Campello, Manola Comar, Pierlanfranco d'Agaro, Anna Minicozzi, Luca Rodella, Albino Poli

\section{To cite this version:}

Cesare Campello, Manola Comar, Pierlanfranco d'Agaro, Anna Minicozzi, Luca Rodella, et al.. A MOLECULAR CASE-CONTROL STUDY ON THE MERKEL CELL POLYOMAVIRUS IN COLON CANCER. Journal of Medical Virology, 2011, 83 (4), pp.721. 10.1002/jmv.22004 . hal-00614691

\section{HAL Id: hal-00614691 \\ https://hal.science/hal-00614691}

Submitted on 15 Aug 2011

HAL is a multi-disciplinary open access archive for the deposit and dissemination of scientific research documents, whether they are published or not. The documents may come from teaching and research institutions in France or abroad, or from public or private research centers.
L'archive ouverte pluridisciplinaire HAL, est destinée au dépôt et à la diffusion de documents scientifiques de niveau recherche, publiés ou non, émanant des établissements d'enseignement et de recherche français ou étrangers, des laboratoires publics ou privés. 


\section{A MOLECULAR CASE-CONTROL STUDY ON THE MERKEL CELL POLYOMAVIRUS IN COLON CANCER}

\begin{tabular}{|r|l|}
\hline Journal: & Journal of Medical Virology \\
\hline Manuscript ID: & JMV-10-2080.R1 \\
\hline Diley - Manuscript type: & Research Article \\
\hline Author: & 08-Oct-2010 \\
\hline Complete List of Authors: & $\begin{array}{l}\text { Campello, Cesare; University of Trieste, Department of } \\
\text { Reproductive, Developmental and Public Health Sciences, and } \\
\text { IRCCS Burlo Garofolo } \\
\text { Comar, Manola; University of Trieste, Department of Reproductive, } \\
\text { Developmental and Public Health Sciences, and IRCCS Burlo } \\
\text { Garofolo } \\
\text { D'Agaro, Pierlanfranco; University of Trieste, Department of } \\
\text { Reproductive, Developmental and Public Health Sciences, and } \\
\text { IRCCS Burlo Garofolo } \\
\text { Minicozzi, Anna; University of Verona, Department of } \\
\text { Anaesthesiology and Surgery } \\
\text { Rodella, Luca; University of Verona, General Surgery Unit, } \\
\text { Endoscopy Service } \\
\text { Poli, Albino; University of Verona, Department of Medicine and } \\
\text { Public Health }\end{array}$ \\
\hline Keywords: & $\begin{array}{l}\text { Merkel cell polyomavirus, colon cancer, molecular case-control } \\
\text { study }\end{array}$ \\
\hline
\end{tabular}

\section{SCHOLARONE" \\ Manuscripts}


Table I. Main pathological features of the cases and controls, and positive results for Merkel cell polyomavirus

\begin{tabular}{|c|c|c|c|c|}
\hline & \multirow[b]{2}{*}{ n. } & \multirow[b]{2}{*}{$\%$} & \multicolumn{2}{|c|}{ ** MCPyV positive } \\
\hline & & & n. $(\%)$ & (95\% CI) \\
\hline \multicolumn{5}{|l|}{ CONTROLS } \\
\hline No lesion & 52 & 65.0 & $4(7.7)$ & $2.09-19.70$ \\
\hline Adenoma & 15 & 18.8 & $2(13.3)$ & $1.61-48.17$ \\
\hline Hyperplastic polyp & 9 & 11.2 & $1(11.1)$ & $0.28-61.91$ \\
\hline Other conditions & 4 & 5.0 & 0 & -- \\
\hline Total & 80 & -- & $7 *(8.8)$ & $3.52-18.03$ \\
\hline \multicolumn{5}{|l|}{ CASES } \\
\hline Adenocarcinoma & 57 & 89.0 & $4(7.0)$ & $1.92-16.1$ \\
\hline $\begin{array}{l}\text { Mucinous } \\
\text { Adenocarcinoma }\end{array}$ & 6 & 9.4 & 0 & -- \\
\hline $\begin{array}{l}\text { Neuroendocrine } \\
\text { cancer }\end{array}$ & 1 & 1.1 & 0 & -- \\
\hline Total & 64 & -- & $4 * \quad(6.3)$ & $1.71-16.01$ \\
\hline
\end{tabular}

*Fisher exact test: $\mathrm{P}=0.755$

** $\mathrm{MCPyV}=$ Merkel cell polyomavirus 
Table II. Nucleotide variation in the viral protein 1 (VP1) gene of two representative Merkel cell polyomavirus sequences (in bold) in comparison with a number of GenBank registered sequences.

\begin{tabular}{lcccccc}
\hline \multirow{2}{*}{ Strain } & GenBank & \multicolumn{6}{c}{ VP1 gene - Nucleotide position } & Country \\
\cline { 3 - 7 } & Accession N & 3825 & 3875 & 3909 & 4023 & \\
\hline MCC350 & EU375803 & T & C & C & T & USA \\
MCC339 & EU375804 & C & G & T & A & USA \\
MKT-23 & FM864208 & C & G & C & T & France \\
MKT-31 & FM864210 & C & C & C & T & France \\
VP1-Mpt2 & AM992903 & C & G & C & A & France \\
MCV ITA 61 & HQ262570 & C & C & C & T & Italy \\
MCV ITA 71 & HQ262569 & C & G & C & T & Italy \\
\hline
\end{tabular}


1 A MOLECULAR CASE-CONTROL STUDY ON THE MERKEL

2 CELL POLYOMAVIRUS IN COLON CANCER

3

4

5

6

11 Hospital of Verona; ${ }^{4}$ Department of Medicine and Public Health,

12 University of Verona.

13 Running title. Merkel polyomavirus and colon cancer

14 Key words. Merkel cell polyomavirus; colon cancer; molecular case15 control study

Affiliations. ${ }^{1}$ Department of Reproductive, Developmental and Public Health Sciences, University of Trieste, and IRCCS Burlo Garofolo, Trieste, Italy; ${ }^{2}$ Department of Anaesthesiology and Surgery, University of Verona, Italy; ${ }^{3}$ General Surgery Unit, Endoscopy Service, Teaching Rumning title. Merkel polyomavirus and colon cancer

Correspondence to: C. Campello, Department of Reproductive, Developmental and Public Health Sciences, University of Trieste, Via dell'Istria 65/1, 34137 Trieste, Italy. Phone +39-040-773433, Fax +39040-7600324; e-mail: campello@burlo.trieste.it.

Grant sponsor: Ministry for University and Research, Italy (PRIN 2007) 3 Word count: 1945 


\section{Abstract}

2 To explore the putative role of the Merkel cell polyomavirus in human

3 colon cancer, a prospective molecular case-control study was undertaken

4 in patients and their relatives enrolled during a screening programme.

5 Fresh tissue samples from 64 cases of colon cancer (mean age $69.9 \pm 11.0$

6 years; 40 males) and fresh biopsies from 80 relatives (mean age $53.7 \pm 8.6$

7 years; 43 male; 55 son/daughter, 23 brother/sister, 2 parents) were

8 analysed by PCR and sequencing. Precancerous lesions, namely

9 adenomas and polyps, were detected in $15(18.8 \%)$ and $9(11.2 \%)$ of the

10 controls, respectively. In addition, 144 blood samples were examined.

11 Merkel cell polyomavirus DNA was detected in $6.3 \%$ of cases and $8.8 \%$

12 of controls. This difference was not statistically significant in the logistic

13 regression analysis, after adjustment for age. Whereas blood samples

14 from both cases and controls tested negative, the DNA Merkel cell

15 polyomavirus was identified in $12.5 \%$ of adenoma/polyp tissues. No

16 statistically significant difference was found when prevalence rates of

17 Merkel cell polyomavirus in normal, precancerous and cancer tissues

18 were compared.

19 Sequence analysis of the viral LT3 and VP1 regions showed high 20 homology (>99\%) with those of strains circulating worldwide, especially 21 with genotypes detected in France. 
1 The findings of this survey are consistent with the hypothesis that the

2 Merkel cell polyomavirus, in addition to other human polyomaviruses,

3 can be recovered frequently from the gastrointestinal tract, because it is

4 transmitted throughout the faecal-oral route. Moreover, the study does

5 not indicate a role for Merkel cell polyomavirus in the genesis of colon

6 cancer.

7 Word count:249

8

9

10

11

12

13

14

15 
2 Merkel cell carcinoma is a rare skin cancer that originates from

3 neuroendocrine cells. This pathological condition has been related

4 recently to infection with a novel human polyomavirus, the Merkel cell

5 polyomavirus [Feng et al., 2008; Zur Hausen, 2008; Becker et al., 2009].

6 Like SV40 [Vilchez and Butel, 2004], Merkel cell polyomavirus appears

7 to play a causal role in tumorigenesis. Tumour induction and expansion is

8 preceded by a monoclonal integration of the virus into target cells.

9 Nonsense mutations or deletions in the early genomic region lead to the

10 expression of truncated large $\mathrm{T}$ antigen, loss of viral DNA replication,

11 and cell transformation [Shuda et al., 2008].

12 The assumed oncogenic power of the Merkel cell polyomavirus has

13 prompted research to explore its role in several human cancers, namely in

14 non-Merkel skin tumours, in neuroblastoma and other malignancies of the

15 central nervous system, in lung cancer, and mesothelioma. A series of

16 high-grade neuroendocrine tumours from different body sites was also

17 investigated, with negative results [Duncavage et al., 2009; Gandhi et al.,

18 2009; Sastre-Garau et al., 2009].

19 Other polyomaviruses, namely JCV and SV40, have been linked

20 previously to colon cancer [Markovics et al., 2005; Campello et al., 2010;

21 Gjoerup and Chang, 2010]. The hypothesis that polyomaviruses and

22 gastrointestinal malignancies are associated relies on several reports in 
1 which sequences of JCV were detected in cancerous tissue, with different

2 rates of prevalence at distinct times and in different geographic areas. In

3 addition, a number of pathogenetic steps in the tumorigenesis associated

4 with JCV have been described [White and Khalili, 2004]. A further

5 rationale for the investigation of Merkel cell polyomavirus in colon

6 cancer is that its epidemiological pattern is similar to that of JCV. It has

7 been demonstrated recently that DNA sequences of both Merkel cell

8 polyomavirus and $\mathrm{JCV}$ can be detected in sewage and environmental

9 samples at high concentrations, thus supporting the faecal-oral route of

10 their transmission [Boffil-Mas et al., 2010; Loyo et al., 2010].

11 Investigations of the possible association between Merkel cell

12 polyomavirus and colon cancer are rare. Studies have been carried out

13 solely on formalin-fixed paraffin-embedded archival tissues, and never

14 compared with samples from control subjects enrolled concurrently

15 [Kassem et al., 2009; Loyo et al., 2010]. In addition, the presence of

16 Merkel cell polyomavirus in precancerous lesions of the colon has never

17 been explored.

18 To address these issues, a prospective molecular case-control study was

19 undertaken to detect the Merkel cell polyomavirus in patients with colon

20 cancer and in their relatives, who were used as controls. 


\section{Patients and samples}

2 In the period 2006-2008, patients with colon cancer and control subjects

3 were enrolled consecutively at the Teaching Hospital of Verona, Italy.

4 This study was part of a large screening programme for colon-rectal

5 cancer in the first-degree relatives of any cancer patient newly identified.

6 After informed consent for participation in the principal study had been

7 obtained, colonoscopy was performed under conscious sedation. Among

8 all the relatives screened, the patients in whom a 'large-biopsy' specimen

9 was taken from the colonic mucosa were enrolled because of hyperplastic

10 lesions, inflammation or any other suspicious condition. Specific

11 informed consent was obtained from each participant for the virological

12 survey undertaken on cancerous tissue or colon biopsies in addition to the

13 histological evaluation. Both the main screening study and this molecular

14 case-control study were approved by the Independent Ethics Committee.

15 The cases were 64 patients (40 male) with colon cancer whose histiotypes

16 are reported in Table I. The mean age was 69.9 years, with a $\mathrm{SD}=11.0$.

17 The controls were 80 relatives (43 male; 55 son/daughter, 23

18 brother/sister and 2 parents) with a mean age of 53.7 years, $\mathrm{SD}=8.6$.

19 According to the pathology results, adenoma or hyperplastic polyps were

20 detected in $15(18.8 \%)$ and $9(11.2 \%)$ of the controls, respectively (see

21 Table I). The gender distribution was similar in both groups, while the

22 mean age, as expected, was significantly lower in controls $(\mathrm{p}=0.001)$. In 
1 addition to fresh tissue samples, a blood sample was also taken from each

2 patient and control. All samples were stored at $-80^{\circ} \mathrm{C}$ until analysed. A

3 total of 288 specimens were examined.

\section{Molecular evaluation}

5 The DNA was extracted with a commercial kit (Qiagen, Milan, Italy) and 6 tested for suitability for PCR by amplifying the RNase P gene, as

7 described recently [Comar et al., 2010]. The presence of Merkel cell 8 polyomavirus DNA was detected using a conventional PCR. Specific

9 primer pairs were designed to detect the viral Large T protein (LT3) and

10 the major capsid protein (VP1) of Merkel cell polyomavirus, as described

11 previously [Feng et al., 2008]. Positive controls cloned in plasmid vectors

12 (pcDNA.MCV350) and negative DNA samples were included in each

13 amplification run. Precautions were taken to avoid cross-contamination of

14 the samples by means of unidirectional molecular workflow.

15 Amplification products were sequenced with the Big Dye Terminator

16 Cycle Sequencing Kit v.3.1 and analysed using an ABI Prism 310

17 Genetic Analyzer (Applied Biosystems, Milan, Italy). Contiguous

18 sequences were assembled using the Sequencer 4.5 software (Gene Codes

19 Corp., Ann Arbor, MI). The sequences obtained were matched against

20 those available from GenBank using the BLAST algorithm. The

21 sequences were deposited in GenBank with the accession numbers

22 HQ262569 and HQ262570. 


\section{$1 \quad$ Statistics}

2 The sample size was estimated at 60 cases and 60 controls, assuming a

3 prevalence of infection of $15 \%$ in controls, an $\mathrm{OR}=2, \alpha$ error $=0.05$, and $\beta$

4 error $=0.20$. Chi-square or Fisher exact tests were used to assess

5 differences in frequency, and the Student t-test to evaluate differences in

6 means. A logistic regression model was used to estimate the relationship

7 between virus positivity and colon cancer, with adjustment for age.

\section{Results}

10 Overall, 11 sequences of Merkel cell polyomavirus, encompassing both

11 regions tested, were detected in samples of colon tissue. No blood sample

12 tested positive in either the cases or controls. The distribution of positive

13 results by group and according to pathological features is reported in

14 Table I. The rate of prevalence was $6.3 \%$ in the cases and $8.8 \%$ in the

15 controls. This difference was not statistically significant in the univariate

16 analysis. In addition, the rates of prevalence for preneoplastic lesions,

17 namely adenomas and polyps, were $18.8 \%$ and $11.2 \%$, respectively.

18 When adjusted for age, no significant association was found between the

19 rate of prevalence in cases and controls (prevalence of Merkel cell

20 polyomavirus in colon cancer vs. prevalence in controls: $\mathrm{OR}=4.47$;

$2195 \% \mathrm{CI}=0.61-28.66 ; \mathrm{p}=0.147)$. Furthermore, no significant difference was

22 recorded when cancer was compared with preneoplastic disorders 
$1 \quad(\mathrm{OR}=0.53 ; 95 \% \mathrm{CI}=0.11-2.57 ; \mathrm{p}=0.426)$, and when preneoplastic tissues

2 were compared with normal tissues $(\mathrm{OR}=1.71$; 95\% $\mathrm{CI}=0.35-8.34$;

$3 \mathrm{p}=0.503$ ). Interestingly, the sole neuroendocrine tumour discovered did

4 not harbour Merkel cell polyomavirus.

5 The amplification products of regions LT3 and VP1 were analysed by 6 sequencing to confirm their identification and to assess sequence

7 variability. The sequences of the conserved LT3 region were identical to

8 almost all those published, and in particular to sequences of strains

9 isolated in France (not shown). Two representative sequence patterns of

10 the variable region VP1 are reported in Table II, along with the sequences

11 of prototype strains and of other isolates retrieved from GenBank. The

12 strain MCV-ITA61 was identical to the isolate MKT-31 and to other

13 sequences discovered in France and Australia (GenBank accession 14 numbers FM864211, AM992902, FJ009188/9). The strain MCV-ITA71

15 was identical to MKT23 and to some American and European sequences

16 (GenBank accession numbers FJ392560, FJ649206, AM992904/5). The

17 level of identity of isolates in this survey was higher than $99 \%$ with the 18 reference strain MCC350. Overall, the Merkel cell polyomavirus 19 sequence patterns obtained in this study reproduced those of the 20 genotypes that are circulating worldwide, and especially in France. 
1 The molecular case-control study reported herein was the first to focus on

2 the role of Merkel cell polyomavirus in incident cases of colon cancer

3 enrolled consecutively. Tissue samples were deep-frozen to ensure the

4 preservation of viral components, because the detection of polyomavirus

5 DNA may be impaired when archival fixed samples are tested [Touzé et

6 al., 2009]. Similarly, the consecutive enrolment of controls was

7 conducted from a cohort of subjects who underwent colonoscopy for

8 cancer screening because they were the first-degree relatives of each

9 patient. The enrolment of controls from relatives of the cases allowed

10 correction for two exposure factors that could have been operating. First,

11 past or present exposures to environmental determinants could have been,

12 at least in part, common to the cases and controls. Second, genetic

13 determinants of colon cancer could have been distributed homogeneously

14 in the cases and their relatives. Hence, the control of both factors may

15 have contributed to the disclosure of the putative role of the oncogenic 16 polyomavirus.

17 In this study, Merkel cell polyomavirus DNA was detected in patients

18 with colon cancer, but the rate of prevalence did not differ significantly

19 from that in the well-structured control group. In addition, no Merkel cell

20 polyomavirus sequence was detected in blood samples, thus excluding

21 possible systemic involvement sustained by infection of PBMCs [Shuda 22 et al., 2009]. 
1 The rates of prevalence that are reported herein were compared with those

2 found in other surveys, in particular with those obtained using standard

3 PCR to assess or confirm the presence of polyomavirus DNA by

4 amplifying the same regions [Feng et al., 2008; Bialasiewicz et al., 2009,

5 Goh et al., 2009; Wieland et al., 2009]. The findings of this survey were

6 very similar to those of Feng et al. [2008], who reported a rate of

7 prevalence of $8 \%$ in selected tissues from the gastro-intestinal tract, with

8 the exclusion of tumours [Feng et al., 2008]. Conversely, in an archival

9 series of cases of colon adenocarcinoma, no Merkel cell polyomavirus

10 was detected [Sastre-Garau et al., 2009]. In a small retrospective case-

11 control study, the rates of prevalence that were found by means of real-

12 time PCR were $16 \%$ in specimens of colon cancer and $20 \%$ in control

13 tissues. The study also demonstrated that the viral load was high in the

14 polyomavirus-related cancer (i.e. Merkel cell carcinoma), whereas it was

15 very low in tissues from other sites, for example, the urogenital tract.

16 Tissues from the digestive tract had an intermediate viral load [Loyo et

17 al., 2010]. Thus, the sensitivity of a standard PCR appears to be

18 satisfactory when specimens of colon cancer, precancerous lesions and

19 normal mucosa are compared, and in particular when fresh tissues are

20 investigated. Collectively, these findings do not support the hypothesis

21 that there is an aetiopathogenetic relationship between Merkel cell

22 polyomavirus and colon cancer. The results point towards a simple 
1 involvement of the gastrointestinal tract through the faecal-oral route of

2 transmission of the virus [Feng et al., 2008; Gandhi et al., 2009; Loyo et

3 al., 2010].

4 This study involved a novel evaluation of precancerous tissues, namely

5 adenomas and polyps, in which the rates of prevalence were similar to

6 those of the other intestinal tissues examined. The meaning of these

7 findings remains speculative. The recovery of Merkel cell polyomavirus

8 sequences from tumoral, precancerous and normal tissues should be

9 considered to represent the transient presence of an infectious agent

10 transmitted by the faecal-oral route [Bofill-Mas et al., 2010].

11 Nevertheless, the possibility of the genomic integration of Merkel cell

12 polyomavirus in permissive precancerous cells could be considered, and

13 its significance in the oncogenic process could then be established. In any

14 case, the oncogenic mechanism of Merkel cell polyomavirus differs from

15 that of other polyomaviruses, including JCV, whose detection in

16 adenomas and polyps has been considered to be an important step in the

17 "hit-and-run" theory of tumorigenesis [Jung et al., 2008; Shuda et al., 18 2008].

19 In conclusion, the findings of this study are consistent with the hypothesis

20 that the ubiquitous Merkel cell polyomavirus [Carter et al., 2009] is

21 present fairly frequently in the gastrointestinal tract, and that its causal 
1 role in colon cancer, in addition to the role of other human and simian

2 polyomaviruses, should be reassessed.

3

\section{Acknowledgements}

5 The technical assistance of Mrs M. Nicolis is acknowledged gratefully.

6 The Merkel cell polyomavirus positive control (pcDNA.MCV350) was

7 provided generously by Dr Patrick Moore, NIH AIDS Research \& 8 Reference Reagent Program, Germantown, USA.

10 References

11 Becker JC, Schrama D, Houben R. 2009. Merckel cell carcinoma. Cell

12 Mol Life Sci 66:1-8.

13 Bialasiewicz S; Lambert, SB, Whiley DM, Nissen MD, Sloots TP.

14 2009. Merkel cell polyomavirus DNA in respiratory specimens from 15 children and adults. Emerg Infect Dis 15:492-4.

16 Bofill-Mas S, Rodriguez-Manzano J, Calgua B, Carratala A, Girones R. 17 2010. Newly described human polyomaviruses Merkel Cell, KI and WU 18 are present in urban sewage and may represent potential environmental 19 contaminants. Virol J 7:141-146.

20 Campello C, Comar M, Zanotta N, Minicozzi A, Rodella L, Poli A. 21 2010. Detection of SV40 in colon cancer: a molecular case-control 22 study from Northeast Italy. J Med Virol 82:1197-200. 
1 Carter JJ, Paulson GK, Wipf, GC, Miranda D, Madelein MM Johnson

2 LG, Lemos BD, Lee S, Warcola AH, Iyer JG, Nghiem P, Galloway DA.

3 2009. Association of Merkel cell polyomavirus-specific antibodies with

$4 \quad$ Merkel cell carcinoma. J Natl Cancer Inst 101:1510-22.

5 Comar M, Zanotta N, Bovenzi M, Campello C. 2010. JCV/BKV and

6 SV40 viral load in lymphoid tissues of immunocompetent children from

7 an area of North East- Italy. J Med Virol 82:1236-40.

8 Duncavage EJ, Le BM, Wang D, Pfeifer JD. 2009. Merkel cell

9 polyomavirus: a specific marker for Merkel cell carcinoma in

10 histologically similar tumors. Am J Surg Pathol. 33:1771-7.

11 Feng H, Shuda M, Chang Y, Moore PS. 2008. Clonal integration of a 12 polyomavirus in human Merkel cell carcinoma. Science 319:1096-1100.

13 Gandhi RK, Rosenberg AS, Somach SC. 2009. Merkel cell 14 polyomavirus: an update. J Cutan Pathol 36, 1327-9.

15 Gjoerup O, Chang Y. 2010. Update on human polyomaviruses and 16 cancer. Adv Cancer Res 106:1-51.

17 Goh S, Lindau C, Tiveljung-Lindell A, Allander T. 2009. Merkel cell 18 polyomavirus in respiratory tract secretions. Emerg Infect Dis 15:4891991.

20 Jung WT, Li MS, Goel A, Boland CR. 2008. JC virus T-antigen 21 expression in sporadic adenomatous polyps of the colon. Cancer $22 \quad 112: 1028-36$. 
1 Kassem A, Technau K, Kurz AK, Pantulu D, Loning M, Kayser G,

2 Stickeler E, Weyers W, Diaz C, Werner M, Nashan D, Zur Hausen A.

3 2009. Merkel cell polyomavirus sequences are frequently detected in

4 nonmelanoma skin cancer of immunosuppresed patients. Int J Cancer $5 \quad 125: 356-61$.

6 Loyo M, Guerrero-Preston R, Brait M, Hoque MO, Chuang A, Kim M.S,

7 Sharma R, Liégeois NJ, Koch WM, Califano JA, Westra WH, Sidransky

8 D. 2010. Quantitative detection of Merkel cell virus in human tissues

9 and possible mode of transmission. Int J Cancer 126:2991-6.

10 Markovics JA, Carroll PA, Sàenz Robles MT, Pope H, Coopersmith

11 CM, Pipas JM. 2005. Intestinal dysplasia induced by simian virus $40 \mathrm{~T}$

12 antigen is independent of p53. J Virol 79:7492-502

13 Sastre-Garau X, Peter M, Avril MF, Laude H, Couturier J, Rozenberg F,

14 Almeida A, Boitier F, Carlott A, Couturaud B, Dupin N. 2009. Merkel

15 cell carcinoma of the skin: pathological and molecular evidence for a 16 causative role of MCV in oncogenesis. J Pathol 218: 48-56.

17 Shuda M, Arora R, Kwum HJ, Sarid R, Fernández-Figueras MT, 18 Tolstov Y, Gjoerup O, Mansukhani MM, Swerdlow SH, Chaudhary 19 PM, Kirkwood JM, Nalesnik MA, Kant JA, Weiss LM, Moore PS, 20 Chang Y. 2009. Human Merkel cell polyomavirus infection I. MCV T 21 antigen expression in Merkel cell carcinoma, lymphoid tissues and 22 lymphoid tumors. Int J Cancer 125:1243-9. 
1 Shuda M, Feng H, Kwun HJ, Rosen ST, Gjoerup O, Moore PS, Chang

2 Y. 2008. T antigen targets are a human tumor-specific signature for

3 Merkel cell polyomavirus. Proc Natl Acad Sci USA 105:16272-7.

4 Touzé A, Gaitan J, Maruani A, Le Bidre E, Doussinaud A, Clavel C,

5 Durlach A, Aubin F, Guyetant S, Lorette G, Coursaget P. 2009. Merkel

6 cell polyomavirus strains in patients with Merkel cell carcinoma. Emerg

$7 \quad$ Infect Dis. 15:960-962

8 Vilchez RA, Butel JS. 2004. Emergent human pathogen simian virus 40

9 and its role in cancer. Clin Microbiol Rev. 17:495-508.

10 White MK, Khalili K. 2004. Polyomaviruses and human cancer:

11 molecular mechanisms underlying patterns of tumorigenesis. Virol. 324:

12 1-16.

13 Wieland U, Mauch C, Kreuter A, Krieg T, Pfister H. 2009. Merkel cell

14 polyomavirus DNA in persons without Merkel cell carcinoma. Emerg 15 Infect Dis 15:1496-8.

16 Zur Hausen HA. 2008. A specific signature of Merkel cell 17 polyomavirus persistence in human cancer cells. Proc Natl Acad Sci $18 \quad$ USA 105:16063-4. 